\title{
Belief in the Reformation Era: Reflections on the State of Confessionalization
}

\author{
Helmut Puff
}

$\mathrm{T}$ HAT Christian religion pervaded many, if not most, aspects of life in sixteenth-century Europe, even the lives of those who were not Christian, is undisputed. "From birth to death stretched a long chain of ceremonies, traditions, customs, and observances, all of them Christian or Christianized, and they bound a man in spite of himself, held him captive even if he claimed to be free," as Lucien Febvre remarked in 1942 in The Problem of Unbelief in the Sixteenth Century. ${ }^{1}$ Most everyone, including the French writer François Rabelais - the subject of Febvre's study-understood their own existence within the divine order. Accordingly, "a world without God" made little or no sense. Even if, pace Febvre, early modern people occasionally entertained the idea that there was no God, individuals rarely faced charges of atheism, as Francisca Loetz has shown. ${ }^{2}$ Our task in researching early modern religion is, then, to chart religious thought, practice, and experience as a complex and capacious phenomenon-its scope, shape, contours, and dynamics.

For several decades a particular paradigm of historical scholarship has generated remarkably sophisticated insights into the changing place of religion in early modern Europe: confessionalization. Named after the confessio fidei- "an explicit statement of doctrine (Lat., confessio)," as Heinz Schilling put it - confessions were stepping stones in the formation of distinct Christian communities after the breakup of Latin Christianity. ${ }^{3}$

Whereas there is no agreement over what confessionalization denotes, different conceptualizations have something in common. Whether attempts to instill a confessional identity originated in the early 1520s, in 1525 after the end of the Peasants' War, or in 1555 with the Peace of Augsburg, the study of confessionalism placed religion at the center of long-term political, religious, social, and cultural processes of change that engulfed post-Reformation societies. At least initially, proponents foregrounded church- and state-building as twin modernizing forces and linked the emergence of confessional societies to the rise of modernity. It follows that confessionalization seeks to offer "a comprehensive analysis of society," as Schilling's phrase goes. ${ }^{4}$ Put differently, students of confessionalization work toward a veritable Gesellschaftsgeschichte. ${ }^{5}$

${ }^{1}$ Lucien Febvre, The Problem of Unbelief in the Sixteenth-Century: The Religion of Rabelais, trans. Beatrice Gottlieb (Cambridge, MA: Harvard University Press, 1982), 336.

${ }^{2}$ Francisca Loetz, Dealings with God: From Blasphemers in Early Modern Zurich to a Cultural History of Religiousness, trans. Rosemary Selle (Burlington, VT: Ashgate, 2009), 236.

${ }^{3}$ Heinz Schilling, "Confessional Europe," in Handbook of European History 1400-1600: Late Middle Ages, Renaissance, and Reformation, vol. 2: Visions, Programs, and Outcomes, ed. Thomas A. Brady, Jr., Heiko A. Oberman, and James D. Tracy (Grand Rapids, MI: William B. Eerdmans, 1995), 641.

${ }^{4}$ Ibid., 643.

${ }^{5}$ For a useful overview, see Ute Lotz-Heumann, "Confessionalization," in Reformation and Early Modern Europe: A Guide to Research, ed. David M. Whitford (Kirksville, MO: Truman State University Press, 2008), 136-57. She introduces the term Gesellschaftsgeschichte on pp. 136, 138. 
Focusing on the making of confessional communities or selves required that one pay attention to measures that fostered the outlook of belonging to a distinct religious group, different from as well as rivaling others (e.g., catechization, visitation, schooling, censorship). In this sense, confessional religion appears as something shaped by institutions, laws, regulations, and media. This focus on external factors allowed early modernists to view the formation of Lutherans, Catholics, Calvinists, and others in a comparative framework. In addition to intraconfessional studies, scholars of early modern Europe increasingly began to research interconfessional scenarios, exploring contacts, rivalries, and conflicts between confessions in an ongoing effort to shed light on the complex realities of confessional plurality on every level. As a result, research on confessionalization strengthened the transition from a history of religious ideas - a history replete with intellectual breakthroughs, ruptures, and turning points - to a social history of how believers, in different locales and settings, came to believe.

At least in part, the great success of this paradigm over the last thirty years hinges on the fact that studies of confessionalism paralleled comparable scholarly endeavors, such as Norbert Elias's civilizing process, Gerhard Oestreich's social disciplining, Michel Foucault's nexus of discipline and power, or Berndt Hamm's normative centering, to name but a few. ${ }^{6}$ More important, the strength of confessionalization resides in its malleability, adaptability, and resilience as an approach. Over time, the emphasis on twin processes of state- or church-formation gave way to the study of alternative perspectives. Findings in a variety of settings had complicated the notion that confession-building constituted a topdown process. David Warren Sabean found, for example, that peasants in early modern Württemberg had refashioned key rituals of church life according to their own notions and needs. Subjects across the duchy abstained from celebrating communion with others in their village whom they considered to be opponents, competitors, or enemies. After all, the celebration of the Eucharist counted among the most important rituals in actualizing a community. As such, it called upon celebrants to test "the state of their heart." people harbored reservations against others within their midst, they consequently refrained from participating, even if the authorities condemned such practices and ideas.

Studying popular culture as a distinct phenomenon may ultimately prove to be incompatible with confessionalization, since the latter approach focuses on how elite concepts get translated and transformed in long-term processes of mediation and remediation. Still, the ways in which the populace of a particular territory entered the confessional fold offer an aperture onto confession-building-its structures, timing, and outcomes. In a study of Catholic Reform in the empire that, like Sabean's, appeared in Central European History $(C E H)$, Marc R. Forster discovered that "many canons, abbots, monks, and vicars did not make the connection, that was so popular among reformers, between moral and behavioral

\footnotetext{
${ }^{6}$ Norbert Elias, The Civilizing Process: Sociogenetic and Psychogenetic Investigations, trans. Edmund Jephcott (Oxford: Blackwell, 2000); Gerhard Oestreich, Neostoicism and the Early Modern State (Cambridge: Cambridge University Press, 1982); Michel Foucault, Discipline and Punish: The Birth of the Prison, trans. Alan Sheridan (New York: Vintage, 1977); Berndt Hamm, "Normative Centering in the Fifteenth and Sixteenth Centuries: Observations on Religiosity, Theology, and Iconology," trans. John M. Frymire, Journal of Early Modern History 3, no. 4 (1999): 307-54. For a study that brings several such approaches into dialogue, see Philip S. Gorski, The Disciplinary Revolution: Calvinism and the Rise of the State in Early Modern Europe (Chicago, IL: University of Chicago Press, 2003).

${ }^{7}$ David W. Sabean, "Production of the Self during the Age of Confessionalism," Central European History (CEH) 29, no. 1 (1996): 3.
} 
reform and institutional survival." studies on confessional formation map a staggeringly complex, if not murky, religious landscape. The pages of CEH over the past fifty years contain many traces of confessionalization's critical appeal.

Among other things, scholars tested the reach of confessional regimes. If confessionalization was a long-term process that affected many social arenas, including religion, work, family, and community, it seemed apposite to study the limits of religious discipline or confessional etiquette. Ute Lotz-Heumann and Matthias Pohlig pursued this question in CEH in 2007 when examining whether literary texts provided a battleground for confessional disputes. As the authors acknowledged, the literary sphere in the early modern German lands was heterogeneous. Interestingly enough, however, certain genres carved out a space for a supraconfessional religious discourse within this sphere. This was not simply because publishers catered to multiple readerships for mercantile gain. Rather, it appears that, for instance, authors of devotional texts actively pursued a vision of an inclusive Christianity. ${ }^{9}$

This supraconfessional outlook did not disappear entirely with time or with the rise of more fully developed confessional regimes. To be sure, inculcating ideas of confessional distinction took on a new urgency after the Peace of Augsburg, when imperial law formally recognized confessions. Still, processes of enforcing confessional conformity originated at different moments, proceeded at different speeds, and underwent different trajectories. ${ }^{10}$ The overall picture that emerged as a result resists a ready synthesis.

More recently, students of early modern religion have come to embrace constant negotiation as integral to societies where confessions existed side by side in different configurations, and where majoritarian confessional communities sometimes cohabited with members of religious groups who refused to consolidate their beliefs in this manner, such as the Anabaptists. ${ }^{11}$ Contrary to widely held notions of the age as relentlessly divisive, doctrinal differences did not always structure religious (or other) interactions. Whereas irenicism as a theological strand has long been celebrated for its pursuit of an elusive interconfessional peace, scholars within and beyond the mold of confessionalization have started to explore a whole range of everyday practices that allowed for peaceful religious cohabitation. Attending church services in a place with a different confession but within reach of one's actual residence (Auslauf), in private chapels that were open to outsiders, and in Simultankirchen (bior multiconfessional churches) of various kinds constituted part of a spectrum of possibilities that challenge views of the confessional age as utterly agonistic and separatist. ${ }^{12}$ Needless to say, religious coexistence was rarely a stable or enduring condition. Between the dawn of the Reformation and the early Enlightenment, interconfessional peace often remained

\footnotetext{
${ }^{8}$ Marc R. Forster, "The Elite and Popular Foundations of German Catholicism in the Age of Confessionalism: The Reichskirche," CEH 26, no. 3 (1993): 315.

${ }^{9}$ Ute Lotz-Heumann and Matthias Pohlig, "Confessionalization and Literature in the Empire, 1555-1700," CEH 40, no. 1 (2007): 35-61.

${ }^{10}$ This is a point made in Jesse Spohnholz, The Tactics of Toleration: A Refugee Community in the Age of Religious Wars (Newark: University of Delaware Press, 2011).

${ }^{11}$ For the Urban Reformation, see Christopher W. Close, The Negotiated Reformation: Imperial Cities and the Politics of Urban Reform, 1525-1550 (Cambridge: Cambridge University Press, 2009).

${ }^{12}$ Benjamin Kaplan, Divided by Faith: Religious Conflict and the Practice of Toleration in Early Modern Europe (Cambridge, MA: Harvard University Press, 2007). See also idem, "Fictions of Privacy: House Chapels and the Spatial Accommodation of Religious Dissent in Early Modern Europe," American Historical Review 107, no. 4 (2002): 1031-64.
} 
brittle and faced many challenges. Confessional relations hinged on local contingencies that were subject to change. At certain moments, neighborly (in)difference led to outbreaks of violence, expulsions, and the like. Highlighting a couple of confrontations, C. Scott Dixon has argued-again, in the pages of $\mathrm{CEH}$ - that the relations between Lutherans and Catholics became more and more fraught on the eve of the Thirty Years' War. ${ }^{13}$ These caveats notwithstanding, recent research has brought to the fore how people made peace with the realities of a multiconfessional society in a variety of ways.

To be sure, people were not indifferent to religious ideas-quite the contrary, in fact. Matters of theology registered as vital. Moreover, they aroused great interest throughout this period. Religious discussions, debates, and controversies involved many individuals. It is important that, at different junctures, laymen and laywomen participated in exchanges on religious subject matter-on the streets, in separate social circles and associations, in churches, or in writing. ${ }^{14}$ Already in the 1520s, the Eucharist emerged as a ritual whose meanings and liturgies were in need of definition. Its corporatist signification, establishing the very community where the ritual took place, was of concern to both the laity and the clergy. In a letter of March 1523, Engelhard Mohr, a verger in Halle, approached Thomas Müntzer as an authority on spiritual matters to "please draw back the veils around the eucharist for me, so that I can approach it more easily, for I am vexed by all the different customs, ideas and speculations relating to it" ( $v t$ de eucharistia mihi vela soluas, quo facilior mihi patefiat aditus, cum tot modis, tot cogitationibus totque speculationibus hinc inde [sim] vexatus). ${ }^{15}$ Müntzer's response (if indeed he responded) does not survive. It is unlikely, however, that he would have issued a statement akin to the confessiones fidei of later years, with their carefully calibrated language and doctrinally distinct stipulations. In the early Reformation, the conception of a living faith was of consequence to many reformers, not only those we have come to call radical. As Martin Bucer stated in a sermon held in 1531, when the city of Augsburg was divided over the issue of the sacraments: "We call Sacramenta the means, through which God works and deals with us, and wish it thus understood," adding that one should "leave disputing and instead love one another" (Wir nennents Sacramenta mittel, darduorch Got mit unns wircket, vnd hanndlet, vnnd wellens also verstan, vnd von disputieren lassen, Euch vnder einannder lieben). ${ }^{16}$

For early Reformation Augsburg, Lee Palmer Wandel has uncovered striking fluidity in how clerics handled and understood the Eucharist. At any rate, as performed, this sacrament did not always conform to particular theological positions, be they Lutheran, Zwinglian, or any other. Nor did they aim to do so. The reformers apparently looked to Scripture as a guide in the matter, and such an approach entailed a certain leeway for believers in experiencing Christ's presence. ${ }^{17}$ Surprisingly, a 1571-1573 visitation in the bishopric of Münster in

\footnotetext{
${ }^{13}$ C. Scott Dixon, "Urban Order and Religious Coexistence in the German Imperial City: Augsburg and Donauwörth, 1548-1608,” CEH 40, no. 1 (2007): 1-33.

${ }^{14}$ See, e.g., Robert J. Christman, Doctrinal Controversy and Lay Religiosity in Late Reformation Germany: The Case of Mansfeld (Leiden: Brill, 2012).

${ }^{15}$ Thomas Müntzer, Collected Works, ed. and trans. Peter Matheson (Edinburgh: T. \& T. Clark, 1988), 55; idem, Briefwechsel, ed. Siegfried Bräuer and Manfred Kobuch (Leipzig: Evangelische Verlagsanstalt, 2011), 159.

${ }^{16}$ Quoted in Lee Palmer Wandel, The Eucharist in the Reformation: Incarnation and Liturgy (Cambridge: Cambridge University Press, 2006), 65.

${ }^{17}$ Ibid., 46-93.
} 
Westphalia revealed that many priests had accommodated their parishioners' desire to receive communion in both kinds. They did so against Catholic tradition, though how they conducted (and subsequently justified) their manipulations varied. By obscuring correspondence between words and acts, doctrine and practice, they evidently tried to uphold the semblance of religious cohesion in their parish. ${ }^{18}$

In recent years, some studies have profiled individuals who thwarted or defied the binding confessional consensus in a particular place or context. One of them was the astronomer Johannes Kepler, whose "commitment to the idea of a single church proved to be the most radical form of a denial of confessions," as Maximilian Lanzinner has written in an article that appeared in 2003 in $C E H .{ }^{19}$ In the case of Kepler, there is reason to presume that his scientific curiosity had something to do with his nonconfessional outlook. ${ }^{20}$ As a rule, early modernists present evidence for confessionlessness as exceptional. But while certainly not the norm, Kepler was not alone in crafting a personal stance on one's confession. The occasions when certain people expressed distance, if not dissent, from confessional standards varied. What is more, whether such expressions surfaced in diaries and letters, or during an official hearing, is of import, since outward compliance was an option in many circumstances.

It is worth noting, at the same time, that various believers expressed disinterest or various degrees of criticism vis-à-vis a confessionally conceived Christianity or a dominant confession. Like Domenico Scandella, the sixteenth-century Friulian miller who went by the sobriquet Menocchio, they claimed the "right to assume an independent stand" from the one the religious or confessional establishment prescribed. ${ }^{21}$ In another instance, the nuns of a disbanded convent in Saxony acted opportunistically, creatively, and evasively when responding to the pressures the Protestant authorities exerted on them to adopt the new social and religious decorum. ${ }^{22}$ There is good reason to doubt that firm confessional identities set the tone in many contexts-let alone everywhere. The doubts that agents of confessionalism voiced about their own success did not appear out of thin air; their anxieties about the progress of the reforms accompanied those reforms as they unfolded. Such pessimistic assessments of the confessional state of affairs offered incentives for generations of reformers to remain steadfast or increase their efforts; this was one of the motors of confessionalization.

Simply put, religious affiliation often was a pragmatic affair. Catharina Margaretha Linck (1687-1721) received a religious education in one of the most famous schools of her time, the one run by Hermann August Francke. Before turning twenty, she left Halle to join a group of Protestant radicals for whom she later preached in Nuremberg, where unorthodox activities of this kind were not tolerated. She subsequently assumed a male persona, which allowed her to fight as a soldier. As a person of meager resources, Linck converted to Catholicism and then back to Lutheranism, both for modest monetary gain and for social

\footnotetext{
${ }^{18}$ David M. Luebke, Hometown Religion: Regimes of Coexistence in Early Modern Westphalia (Charlottesville: University of Virginia Press, 2016), 74-103.

${ }^{19}$ Maximilian Lanzinner, "A Man without Confession in the Age of Confessionalization?," CEH 36, no. 4 (2003): 544.

${ }^{20}$ See also Ulinka Rublack, The Astronomer and the Witch: Johannes Kepler's Fight for His Mother (Oxford: Oxford University Press, 2015).

${ }^{21}$ Carlo Ginzburg, The Cheese and the Worms: The Cosmos of a Sixteenth-Century Miller, trans. John and Anne Tedeschi (Baltimore, MD: Johns Hopkins University Press, 1980), 11.

${ }^{22}$ Marjorie E. Plummer, "Where Are They Now? The Experiences of Protestant and Catholic Nuns after Confronting the Reformation," unpublished paper at the 2017 Sixteenth Century Studies Conference, Milwaukee, WI, Oct. 26, 2017.
} 
recognition, one suspects. Wanderings across central Europe made her various reinventions possible. Her life ended tragically, however, when she married another woman in the guise of a man-an offense for which she was executed. ${ }^{23}$ Linck's biography is certainly not typical. But her story, the subject of a contemporary pamphlet, is a reminder that religious distinctions were permeable, be it by conversion or by other steps, at a time when confessions had taken root. ${ }^{24}$

Studies on, or critical responses to, confessionalization have, then, catapulted our knowledge of early modern Europe's religious landscape to a new level. At the same time, the various pressures on this paradigm have stretched the assumptions that have long shaped studies of this "fundamental" process to the breaking point. ${ }^{25}$ When reviewing the state of confessionalization, Lotz-Heumann concluded in 2008 that its explanatory force had suffered from the findings in the studies she surveyed for her essay, though she added that the thematic remains pivotal. ${ }^{26}$ Since then, other studies have further challenged the notion that confessionalization was a hegemonic force in early modern societies.

What comes next? The field as a whole would benefit from approaching the early modern religious domain as enabling and empowering. It is worth recalling how Febvre, in the passage quoted earlier, described belief: religion, he wrote, "bound a man in spite of himself, held him captive even if he claimed to be free." Such a formulation may sound dated. Yet, what it conveys - a concept of religion as invasive to the self-still resonates today. Instead, researchers need to cast light on how sixteenth-century believers actively forged their religious sensibilities. Even the disciplinary terrain that confessionalization circumscribes brims with agential possibilities. For those who decided to serve a particular confessional agenda, doing so intensified their religious agency in working toward a new confessional society and setting an example for others to follow. Investing our discussion of confessional regimes with a renewed sense of personal possibilities constitutes a marked departure from the current paradigm, with its emphasis on fulfilling religious standards alien to one's self. ${ }^{27}$

Lucien Febvre may have had a point when he claimed that "there is not the slightest work of a general nature on the history and practice of piety in the sixteenth century." 28 In the meantime, many investigations of religious praxis, different emotional communities, and similar themes have seen the light of day. ${ }^{29}$ Still, religious experience remains little studied from a cultural angle. Researchers usually zoom in on religious subjects case by case- and not with an eye to mapping the broad social and cultural terrain of such engagements. At any rate, a view of the religious-confessional scenery that weds possibilities and potentials

\footnotetext{
${ }^{23}$ Angela Steidele, In Männerkleidern: Das verwegene Leben der Catharina Margaretha Linck alias Anastasius Lagrantinus Rosenstengel, hingerichtet 1721: Biographie und Dokumente (Cologne: Böhlau, 2004).

${ }^{24}$ On this topic, see David M. Luebke, Jared Poley, Daniel C. Ryan, and David W. Sabean, eds., Conversion and the Politics of Religion in Early Modern Germany (New York: Berghahn, 2012).

${ }^{25}$ Heinz Schilling, "Confessionalization in the Empire: Religious and Societal Change in Germany between 1555 and 1620," in Religion, Political Culture and the Emergence of Early Modern Society: Essays in German and Dutch History (Leiden: Brill, 1992), 209.

${ }^{26}$ Lotz-Heumann, "Confessionalization," 149.

${ }^{27}$ See also Marc Forster, Bruce Gordon, Joel Harrington, Thomas Kaufmann, and Ute Lotz-Heumann, "Religious History beyond Confessionalization," German History 32, no. 4 (2014): 579-98.

${ }^{28}$ Febvre, The Problem of Unbelief, 335.

${ }^{29}$ As one example among many, see Susan C. Karant-Nunn, The Reformation of Feeling: Shaping the Religious Emotions in Early Modern Germany (Oxford: Oxford University Press, 2010).
} 
to the social control mechanisms and disciplinary oversight remains a desideratum. In short, then, let us bestow a sense of selfhood on those who are, for the most part, said to have been subjects only, in the sense of being subject to the authorities of confessionalism. ${ }^{30}$ Let us cast off what remains of a functionalist approach to religion. Let us study religious subjectivities in the confessional age, and let us do so systematically.

University of Michigan, Ann Arbor

${ }^{30}$ For a good example of this kind of work, see Erin Lambert, Singing the Resurrection: Body, Community, and Belief in Reformation Europe (Oxford: Oxford University Press, 2017). 